\title{
Communication Strategy of Kasepuhan Sinar Resmi Community In Maintaining Local Varieties For Strengthening Leuit (Village Barns)
}

\author{
Mas Ayu Ambayoen ${ }^{1, *}$, Bayu Adi Kusuma ${ }^{1}$, Resya Eka Pratiwi ${ }^{1}$ \\ ${ }^{1}$ Socio-Economics Department, Agriculture Faculty, Brawijaya University, Indonesia \\ * Email: ayoen_maa@yahoo.co.id
}

\begin{abstract}
Village food barn is one concept of food security based on local wisdom that is able to maintain the stability of food supply of the community. Leuit (barns) for Kasepuhan Sinar Resmi Community is a tradition of harvesting of rice that still exists today. The harvests stored in Leuit come from local varieties that are still preserved its authenticity. There are about 68 local varieties that are still cultivated by the Kasepuhan community. The results of this study indicate that there is a communication strategy conducted by Kasepuhan Sinar Resmi community in maintaining local varieties and Leuit sustainably. The communication strategy is reflected in the oral tradition from generation to generation. As a society, that still follows the paternalistic culture; the role of traditional leader is very dominant. In addition, customary values and norms are still well maintained, such as taboo culture (pamali), selling crops and the sharing of local varieties grown to maintain the existence of Leuit sustainability and their local genetic resources.
\end{abstract}

Keywords: communication strategies, local varieties, leuit, local genetic resources

\section{INTRODUCTION}

Food is the main need for humanity among other needs. Food security is the availability or adequacy of food and accessibility of food by members of the community. Referring to the definition contained in Law No. 18 of 2012 on food, food security is the condition of the fulfillment of food for the state up to the individual which is reflected from the availability of adequate food, both quantity and quality, safe, diverse, nutritious, equitable and affordable. Rice farming received special attention from the government because in general rice is the staple food for the population of Indonesia.

Fulfillment of rural food security cannot be separated from the institution of village granary that can accommodate the harvest. According Widodo (2016), food barn is one of the institutions that exist in society that has long played a role in the procurement of food, especially in the famine season. The role of granaries in the past is more social and as a place to store crops that can be utilized by people in the famine season. One of the strengths in the development of community food reserves is the tradition of individual farming communities to set aside the crops for food reserves is still relatively high.

Various regions in Indonesia have the shape, type and function of the barn varies according to the tradition and local wisdom of the community. One indigenous community that still exists and continues to maintain their noble cultural values, especially in the cultural system of agriculture is the official Kasepuhan Sinar Community. The majority of Kasepuhan Sinar Resmi live from agriculture, especially rice plants. One of the food security embodied is a local food barn known as the leuit system (traditional rice barn).

According to Witoro, et al (2006), not only do barns serve to store rice for consumption, but also those are used as storage of various seeds of plants. As happened to Leuit in Kasepuhan Sinar Resmi, Sirna Resmi Village, Sukabumi, West-Java, the barn is also as a means of storing various local rice varieties that are still preserved to this day. Communication strategy and communication channel done at Kasepuhan Sinar Resmi society is very important to be studied in order to be applied to other region, especially in building local independence. 
The purpose of this research are: (1) to describe the management of Leuit (village granary) Kasepuhan Sinar Resmi; (2) to identify local rice varieties of the Official Sinar Kasepuhan Society; (3) to analyze the community communication strategies undertaken in maintaining local rice varieties.

\section{RESEARCH METHODS}

This research type is descriptive with qualitative approach. Data collection is done by indepth interview to some of Kasepuhan Sinar Resmi community leaders. It also use literature studies from previous studies related to leuit and local varieties of Kasepuhan Sinar Resmi as well as relevant sources of information. Data analysis was done by Qualitative Analysis of Miles and Huberman consisting of data reduction, data condensation, data presentation, and conclusion/ verification. Furthermore, the validity of data is done by triangulation of sources and methods.

\section{RESULTS AND DISCUSSION}

\section{Management of Leuit (Village Granary) Kasepuhan Sinar Resmi}

\section{Description of Indigenous Peoples Kasepuhan} Sinar Resmi

The indigenous people of Kasepuhan Sinar Resmi are local people in the area of Sirna Resmi Village, Cisolok District, Sukabumi Regency. Geographically, these Sundanese indigenous people live around Mount Halimun Salak National Park (TNGHS). Its total area is about 4,917 ha, most of it in the form of protected forest.

Head of custom of Kasepuhan Sinar Resmi is Abah Asep Nugraha. History Kasepuhan Sinar Resmi has a relationship with the existence of the Kingdom of Padjajaran and also the existence of
King Prabu Siliwangi. Kasepuhan Sinar Resmi is located in Desa Sirna Resmi, along with two other kasepuhan, Kasepuhan Cipta Mulya and Kasepuhan Cipta Gelar. These three blisters are mutually interconnected and still in one lineage. Based on the information of some community leader, the emergence of the Kasepuhan community started from the destruction of the Pajajaran Kingdom as a result of war with Banten.

In accordance with the mandate of the establishment of Kasepuhan to save the agricultural system of the Kingdom of Pajajaran, until now the agricultural system conducted by members of the Kasepuhan community is still a rain-fed rice farming system with a pattern of planting once a year. This also causes most people still choose the profession as a farmer, some others as farm laborers, as well as several other professions as can be seen in the picture below.

\section{Description of Leuit Kasepuhan Sinar Resmi}

According to Rachmat et al (2010), the food barn is a food reserve that serves to maintain the stock or stability of food either due to famine season or because of emergency conditions such as natural disasters. The granary in the community includes three kinds of them:

1) Individual barns, used as storage of individual household production that produce food.

2) Group barn, a barn built by a community group with the aim of addressing the food insecurity of a particular group, with members of a foodinsecure group.

3) Village barn is a granary built on the initiative of village officials in overcoming food insecurity of village communities. Village government facilitates the establishment of barns.



Figure 1. Professional Distribution of Kasepuhan Sinar Resmi 
The concept of leuit, which is in the eyes of the community as a form of homage to Dewi Sri, actually has functioned as food security for the people of that society. The presence of leuit took part in regulating the availability of food in villages far enough from urban areas. There are two types of leuit, the leuit the amulet belongs to all the citizens, and the leuit of the individual/ citizen. Every citizen obliged to set aside two pocongs (two bundles) from the harvested harvest to leuit the amulet.

Leuit management is directly under the supervision of the Adat Chairman. It is used for: the supply of needs in the Kasepuhan community, as well as when urgent can be expelled or taken and used, for example for the needs of the time of the famine, while the road construction activities gotong royong, marriage, there are families who died, and so forth.

There are some Leuit related rules that must be obeyed by Kasepuhan Sinar Resmi that is:

- Each harvest 50 unit which is called 'pocong', then the residents must submit 1 pocong of rice, which is equivalent to $3 \mathrm{~kg}$ of rice to be impaled in leuit the fetish (leuit community).

- Rules for not selling rice crops. Usually it will be estimated how long the supply of rice in Leuit. Under certain conditions then allowed to sell rice, provided that the stored rice can meet food needs up to four years into the future. This is in accordance with the results of interviews with Abah Asep (Chairman of Adat Kasepuhan Sinar Resmi), namely:

".....The indigenous peoples of

Kasepuhan Sinar Resmi have customary

rules that do not allow the sale of rice,

rice or the like ....."

(Source: interview March, 2017)

The indigenous people of Kasepuhan have customary rules that do not allow the sale of rice, rice or the like. This is because the Kasepuhan people have a tradition to glorify rice as their source of life and as the embodiment of Nyi Pohaci on Earth. In addition, this customary regulation creates an atmosphere of mutual cooperation in the Kasepuhan region. If someone does not have rice for cooking then he/she can take the rice from the communal leuit.

\section{Identification of local rice varieties of Kasepuhan Sinar Resmi Meaning and Advantages of local varieties}

In accordance with the provisions of legislation number 29 of 2000, states that "local varieties are varieties that already exist and are cultivated for generations by farmers and belong to the community and controlled by the state". The use of local superior varieties is still done by the Kasepuhan community to date. According to Zulkha, Sulusy (2013), the superior properties of local varieties are: more resistant to pests and diseases, unresponsive to chemical fertilizers so that without the use of chemistry fertilizer can produce optimally, and generally have the taste and the storability better than new rice varieties. Rice grown in Kasepuhan generally has the following characteristics:

- Larger and taller rods

- Average height reaches one meter

- Local rice age is categorized in the average age of six months

- Have more number of grains

- Grain tail.

Various types of local rice grown, Kasepuhan people are able to achieve the status of Rice SelfSufficiency. Leuit in the eyes of the community is considered a form of respect for Dewi Sri, which serves as a form of food security for residents Kasepuhan Sinar Resmi. Using such the concepts, people are forced to store rice in leuit and regulate the way their consumption.

Production of local varieties rice seed is indispensable in supporting national food security. Local rice management in Kasepuhan Sinar Resmi is still influenced by local customs or agricultural practices, such as: abstinence from selling rice and rice, abstinence from planting rice twice, and abstaining from using sickle in harvesting. Kasepuhan people grow rice with a variety of local varieties. Local rice plants are used for food needs Kasepuhan not traded. One of the guarded rules is that rice cultivation should only be planted once a year. Planting rice once a year has proven to be able to control the development of pests, diseases, and maintain soil fertility, because the land is given a chance to rest. The ban on the use of chemical pesticides in Kasepuhan has been tested to prevent the development of pests and diseases on a large scale. According Widodo (2016), chemicals (fertilizers and pesticides), raises concerns in the form of pollution, environmental 
damage, environmental sustainability. Ancestors used green manure and cages to maintain soil fertility, breed their own seeds, natural biological balance with customary restrictions.

Kasepuhan Sinar Resmi is one of Kasepuhan which still maintain the values of tradition and farming system inherited from ancestors generation to generation. Kasepuhan is included in the Unity of Banten Kidul Customary which still maintains the local rice wealth which is estimated there are as many as 68 local types of rice. Seeds cultivated by local communities have healthier advantages in terms of health, superiority in taste, pest and disease resistance, local rice has become part of indigenous life that can not be separated.

\section{Local varieties Kasepuhan Sinar Resmi}

Based on the interviews with some residents and Abah Asep himself, stated there were 68 previously recorded local varieties of seeds in Kasepuhan. But over time, local rice seeds that can be accounted for at this time more or less recorded there are as many as 30 local varieties of paddy fields and fields, which is usually planted Kasepuhan Sinar Resmi community. Some of these varieties are: Maliwarna, Salak Rice, Randa Rich Rice, Rice Jamudin, Ketang Rayung, Ketan Bilatung, Ketan Nangka, Kapundung Bodas, Cere Marilen, White Rumbai, Nemol Rice, and so forth. In addition, there are also varieties that have been registered in Plant Variety Protection and Agricultural Licensing (PVTPP) as many as 15 types as in the following table.

Table 1. List of Rice Varieties Kasepuhan Sinar Resmi Registered at PVTPP

\begin{tabular}{cl}
\hline Number & \multicolumn{1}{c}{ Names Varieties } \\
\hline 1. & Dete Sinar Resmi \\
2. & Cere Marilen Sinar Resmi \\
3. & Sri Kuning Sinar Resmi \\
4. & Cere Layung Sinar Resmi \\
5. & Cere Kawat Sinar Resmi \\
6. & Raja Denok Sinar Resmi \\
7. & Srimahi Sinar Resmi \\
8. & Cere Gempol Sinar Resmi \\
9. & Ketan Cikur Sinar Resmi \\
10. & Seksek Sinar Resmi \\
11. & Ketan Bledug Sinar Resmi \\
12. & Ketan Hideung Sinar Resmi \\
13. & Terong Bereum Sinar Resmi \\
14. & Panca Warna Sinar Resmi \\
15. & Nemol Sinar Resmi \\
\hline Soure PVTPP 2017
\end{tabular}

Source: PVTPP, 2017
Kasepuhan community in preserving the local seed varieties by way of traditional cultivation using traditional patterns made Kasepuhan farmers. According to the results of interviews with the Chairman of Adat, namely:

“...Cara mempertahankeun benih padi lokal anu aya di Kasepuhan, carana setiap wargi kedah melak di ladang atanapi sawah nyalira, minimal tilu- lima varietas padi anu dipelak, anu masingmasing varietasna di pelak bentenbenten..."

(... How to maintain the local rice seeds in Kasepuhan by means of each citizen planting in his own fields or rice fields with at least three - five varieties of rice planted with each variety planted differently for each citizen...)

(Source: interview March, 2017)

Local rice varieties are rice varieties that have long been adapted in certain areas. So these varieties have location-specific characteristics in the area. Each variety has advantages and disadvantages. Similarly, for local varieties, for example in the area of rice varieties Kasepuhan include: According to the results of interviews with Mr. Omid namely:

"... To preserve local varieties of seeds, farmers have to plant each year originally, not to replace new ones / can turn crops with neighbors or other ..." (Source: interview March, 2017)

\section{Community communication strategies undertaken in maintaining local rice varieties}

According to Cangara, Hafied (2013), communication strategy is the best combination of all communication elements ranging from communicators, messages, channels (media), recipients to influences (effects) designed to achieve optimal communication goals. Communication strategy conducted by Kasepuhan Sinar Resmi is interpersonal communication conducted by Adat Chairman as Sourc/ main source in message delivery and exemplary for people who still thick with paternalistic culture. The rule for maintaining local rice varieties is to require the community to plant at least 3 different types of varieties. The channel used is an interpersonal communication channel. There are internal and external factors that influence the 
communication strategy. Internal factors consist of: values and norms that are still adhered to, a strong paternalistic culture, the dominant role of Traditional Characters, and the preserved Seren Taun tradition. While external factors include: The existence of Law No.29 of 2000 on the protection of varieties and Institutions Initiation outside Kasepuhan Sinar Resmi.

The internal and external factors that influence local wisdom Kasepuhan Sinar Resmi in maintaining the continuity of Leuit are as follows.

\section{Internal factors}

- Values and Norms

Some of the values and norms that are still held by Kasepuhan Sinar Resmi are as follows.

Table 2. Local wisdom of Kasepuhan Sinar Resmi

\begin{tabular}{|c|c|}
\hline $\begin{array}{c}\text { Local } \\
\text { Wisdom }\end{array}$ & Pamali Culture \\
\hline Value & Talek (Rules) \\
\hline Norms & $\begin{array}{l}\text { - Prohibition to sell rice and rice. } \\
\text { - Prohibition to use the machine } \\
\text { in making grain into rice. } \\
\text { - Prohibition to use modern tools } \\
\text { in cultivating agricultural land. } \\
\text { - The allowed planting period is } \\
\text { only one time. After harvest the } \\
\text { land is used to plant crops. } \\
\text { - Planting time synchronously. } \\
\text { - Everyone is required to plant at } \\
\text { least } 3 \text { different types of local } \\
\text { rice varieties. }\end{array}$ \\
\hline $\begin{array}{l}\text { Sancti } \\
\text { ons }\end{array}$ & $\begin{array}{l}\text { All violations of the rules are } \\
\text { believed to bring in } \\
\text { reinforcements. }\end{array}$ \\
\hline
\end{tabular}

Source: interview March, 2017.

- Paternalistic culture

According to Agus (2016), paternalism is a system that places the leadership as the most dominant party. Paternalism thrives because it is influenced by the feudal culture that most of the territory in Indonesia was originally a former territory of the kingdom. The territory of this former kingdom has a system of values, norms and customs that always uphold and glorify the ruler as a person who must be respected because they have given life and shelter for the citizens.
- The role of Traditional Chairman

Data obtained from some informants about the role of traditional chairman in maintaining local wisdom in Kasepuhan Sinar Resmi, in giving motivation, spirit and various development activities in Kasepuhan Sinar Resmi development. The duties of the Traditional Chairman are: 1). foster and develop customary values in order to enrich, preserve and develop culture; 2). maintain, preserve and utilize the wealth of indigenous villages for the welfare of indigenous peoples; 3 ). as supreme leader in customary government; 4). leading custom and religious ceremonies.

- Preserving Seren Taun tradition to keep communication between people

The Kasepuhan Sinar Resmi community has a tradition associated with Leuit, namely Seren Taun. This tradition is done every dated 22 Great Kingdom last month Sundanese calendar system. Kasepuhan people perform this ceremony by storing the produce of rice in the barn (Leuit). In addition there is a ritual of eating new rice (the first rice from the harvest). The event is enlivened with various traditional arts of Sundanese. The meaning contained in this ceremony is ngajayak (in Sundanese), which means receiving and welcoming new rice.

\section{External Factors}

- The Law of protection of local varieties

According to Law No. 29 of 2000 on the protection of varieties, the variety of varieties in Kasepuhan Sinar Resmi is entitled to legal protection. Such varieties as customary property will be recognized as one of the local wisdom that must be maintained and preserved.

\section{- The existence of Assistance Institutions outside Kasepuhan}

Currently there is assistance of seed bank program in Kasepuhan Sinar Resmi which is initiated by Dompet Dhuafa and Pertanian Sehat Indonesia (PSI) by assisting Kasepuhan community to collect local seeds, to open special land for seed planting.

The communication strategy applied by Kasepuhan Society can be briefly described as below. 




Figure 2. Communication strategy of Kasepuhan Sinar Resmi

\section{CONCLUSION}

1. Management of Leuit Kasepuhan Sinar Resmi directly under the Traditional Chairman. Leuit is a private and communal leuit. Some rules of Leuit are required for every person after harvest handed 1 bundle of 50 pocong (tied) harvest to be kept in Leuit and should not sell rice crops.

2. Currently there are 15 local varieties of Kasepuhan Sinar Resmi which have been registered in PTVPP. In general, local varieties have the following characteristics:

- Larger and taller rods.

- Average height reaches one meter

- Local rice age is categorized in the average age of six months.

- Have more number of grain paddy.

- Grain tail.

3. Communication strategy conducted by Kasepuhan Sinar Resmi is interpersonal communication conducted by Traditional Chairman as Source/ main source in message delivery. There are internal and external factors that influence the communication strategy. Internal factors consist of: values and norms that are still adhered to, a strong paternalistic culture, the dominant role of Traditional Characters, and the preserved Seren Taun tradition. While external factors include: The existence of Law No.29 of 2000 on the protection of varieties and Institutions Initiation outside Kasepuhan Sinar Resmi.

\section{Suggestion}

Based on the results of these studies can be submitted some suggestions as follows:

1. Communication strategy and communication channel done at Kasepuhan Sinar Resmi society is very important to be applied in other area, especially in developing local food selfreliance.

2. It needs to be done more identification of community groups that still maintain and preserve local varieties of food crops, especially rice.

3. Further sustainable assistance is needed in the local varieties management community to facilitate their various needs in maintaining local varieties, for example: related technical assistance and advocacy for local varieties to obtain formal legitimacy from related institutions such as PVT (Plant Variety Protection).

\section{REFERENCES}

Agus. 2016. Budaya Paternalisme dalam Birokrasi Pelayanan Publik.

http://cpps.ugm.ac.id/publication/budayapaternalisme-dalam-birokrasi-pelayananpublik/:Yogyakarta. Universitas Gajah Mada

Cangara, Hafied. 2013. Perencanaan dan Strategi Komunikasi. Rajawali Pers. Jakarta

Rachmat et al. 2010. Lumbung Pangan Masyarakat: Keberadaan dan Perannya Dalam Penanggulangan Kerawanan Pangan. Forum Penelitian Agro Ekonomi, Vol 29 (1). Pusat Sosial Ekonomi Dan Kebijakan Pertanian.

Supancana, $d k k$. 2011. Laporan Akhir Pengkajian Hukum Tentang Perlindungan Tanaman Lokal Dalam Hukum Nasional dan Internasional. Kemenhum dan HAM. Jakarta.

Witoro, Napiri, Y., dan Sihaloho, M. 2006. Lumbung Pangan: Jalan Menuju Keterjaminan Pangan. Bogor: Koalisi Rakyat Untuk Kedaulatan Pangan (KRKP), Sindangbarang.

Wulandari. Widodo. 2016. Peran Lumbung Pangan Swadaya Dalam Menjaga Ketahanan Pangan Masyarakat Di Desa Giritirto, Kecamatan Purwosari, Kabupaten Gunung Kidul. Program Studi Agribisnis, Fakultas Pertanian, Universitas Muhammadiyah Yogyakarta.

http://repository.umy.ac.id/bitstream/handle/ 123456789/3286/Full\%20Paper-RetnoSeminar\%20Sosek\%20UGM.pdf 
?sequence $=1 \&$ isAllowed $=y$. [Diakses pada Tanggal 12 Februari 2017]

Witoro, Napiri, Y., dan Sihaloho, M. 2006. Lumbung Pangan: Jalan Menuju Keterjaminan Pangan. Bogor: Koalisi Rakyat untuk Kedaulatan Pangan (KRKP), Sindangbarang.
Zulkha, Sulusy. 2013. Dampak Adanya Varietas Padi Impor Ir-64 Terhadap Keberadaan Padi Lokal di Indonesia.

http://www.academia.edu/9665287/dampak_ad anya_varietas_padi_IR64_terhadap_varietas_pa di_lokal. [Diakses pada tanggal 19 Juni 2017] 